\title{
Martial art of Dayak Central Kalimantan (a Study of History, Philosophy, and Techniques of Traditional Martial Arts)
}

\author{
Eko Hernando \\ Graduated Program \\ Universitas Negeri Yogyakarta \\ Yogyakarta, Indonesia \\ eko.hernando2016@student.uny.ac.id
}

\author{
Siswantoyo \\ Graduated Program \\ Universitas Negeri Yogyakarta \\ Yogyakarta, Indonesia \\ siswantoyo@uny.ac.id
}

\begin{abstract}
This study aims to explore how the history of traditional Dayak martial arts in Central Kalimantan, the philosophy contained therein, and the techniques of martial arts in Dayak Central Kalimantan. The research applied a qualitative research with historical research method. The Data sources in the study were obtained through three traditional martial arts colleges in Central Kalimantan, namely; Pangunraun Pitu (East Barito regency), Silat Sakti Salamat Kambe (Katingan regency), and Palampang Panerus Tinjek (Pulang Pisau regency). The data collection techniques used were observation, interviews, and documentation. The results showed that (1) the figure who first spread the martial arts of the Dayak tribe into all parts of Central Kalimantan were two brothers namely; Mahusin Saun (Tinjek) and Salamat Saun (Kambe). (2) The philosophy contained in his domain is very close to the values of Dayak culture through "Lawang Sakepeng" and Islamic values drawn from Arabic letters such as alif lam mim which are represented in form of step movements. (3) Bangkui technique as the most original technique, is a movement inspired by a primate animal (Macaca Nemestrina), it has a very low stance, an attack pattern towards the lower body, with locks that are very difficult to break from.
\end{abstract}

Keywords-martial arts, pencak silat, kuntau bangkui.

\section{INTRODUCTION}

Traditional martial arts or Pencak Silat in the Dayak tribe has been noted across several regions, such Kuntau, playing is one of the original martial arts / martial arts for the "Dayak Ngaju" tribal people in Central Kalimantan, where the Dayak Tribe is an Indonesian sub-nation, a large ethnic group in the Kalimantan region. In its development, this martial art has often been displayed in the "panganten mandai" - a traditional wedding ceremony known as "lawang sakepeng," which is the process of opening an obstacle created for both couples to be able to face all the obstacles and trials in life, and usually it is accompanied by beats of drums and gongs, and in practice is not uncommon for spectators and family members to show their skill in martial art. Kuntau playing, is often collaborated into traditional dances. This traditional self-defense has one of the mainstays of the move, that is "caring." The carcass is one of the martial arts moves whose naming is inspired by the movements of animals called "bangkui" in Dayak language - a type of monkey (primate) that lives in the wilderness of Kalimantan.Also, an English baboon called as Southern pig-tailed which is called macaca nemestrina in Latin.

The bangkui stance is the main or ultimate technique to turn off and lock the opponent's movements because, the bangkui movement itself has a some techniques capable of paralyzing an opponent with just an attack. This traditional martial art tends to use bare hands and relys on the agility of the players' movements, although there are also some martial art practitioners who use weapons. This pattern of the traditional self-defense tends to attack enemies from the bottom and directly attacks the opponent's body's defensive points. Broadly speaking, the traditional martial arts of kuntau, main, bangkui or sakepeng as genuine martial arts of the Dayak indigenous people has experienced a significant decline in popularity, it is now very rare to find people who master this martial arts technique in its entirety.

Today, especially among the young generation, the traditional background of these martial arts is beginng to be excluded and abandoned by the younger generation. This is because the martial arts teachers are reluctant to pass on their martial arts and gradually, the kuntau martial arts, if not preserved, slowly but sure, will be forgotten and eventually not recognized by the next generation, or in other words this martial art will be lost.

\section{A. Pencak Silat}

The self-defense of Pencak Silat is a method of selfdefense that is closely related to art and culture. This relation is because the Pencak silat is a product of art and culture. The surrounding environment is an inspiration for the movements of Pencak silat where the movements, both during attack and defence is mixed by an expert/warrior imitated from behavior of animals and nature who inspire them. Then, every movement has meaning or values of life (philosophical) within and naming the movement. It is adjusted to what inspired it and it becomes a distinctive feature of the martial arts college.

\section{B. Dayak Tribe}

The Dayak tribe is one of the Indonesian sub-nations and a large ethnic group in the Kalimantan region. In Central 
Kalimantan, the Dayak people are called "Uluh Dayak," or "dulun Dayak." Dayak was reffered to as Daya (where this word is more common to the Dayak people in East Kalimantan and West Kalimantan) or Daya Sahawung [1].

The Dayak tribes in Central Kalimantan, which are normally referred to as Ngaju Dayak tribe, are divided into 4 small tribes; 53 small tribes of Dayak Ngaju, 8 small tribes of Dayak Maanyan, 8 small tribes of Dusun Dayak, and 21 small tribes of Dayak Lawangan. However, apart from Dayak Ngaju, another large tribes exisits in Central Kalimantan, known as Dayak Ot Danum and is divided into 7 major tribes, 18 small tribes and 405 families.

\section{Dayak tribe and its relationship with Pencak Silat}

In an open culture, the process of acculturation allows an element of culture to develop. The Malay culture as the majority ethnic group inhabited the archipelago, which had pencak silat as martial arts. Pencak silat martial art is rooted in a Malay clump society which is a whole lot different in features and methods from other martial arts [2]. The Pencak silat martial art according to Siswantoyo is a product of Indonesian culture that has been inherited and passed down for generations, and has existed since the inception of human civilization where nature greatly influenced the creation of a variety of martial arts movements.

\section{Philosophy in martial arts}

Philosophy as a method defines a reflective way of thinking, an investigation using reason, and thinking carefully and acccurately [2]. Philosophy seeks an in-depth understanding of all human experience. The philosophy and values of martial arts are basically the views and wisdom of human life in relation to cultural values, social values, moral values and religious values that are upheld by the community on Pencak silat [3].

Pencak Silat philosophy: "Pencak Silat philosophy is a philosophy of the noble character which gives root to the nobility of human attitudes, behaviors, and actions which is vital to realize religious and moral ideals in the society [4]. The philosophy behind the noble character in humans is to be able to fulfill noble obligations as God's creatures, personal beings, social beings, and creatures of the universe, to improve the quality of important places in the society above personal interests, and to love the natural environment surrounding us. "

\section{E. Basic techniques in Pencak Silat}

There are several elements behind the movement of Pencak silat, including (1) stance, (2) tide, (3) step pattern, (4) attacks, and (5) catches. Suryo (2014) explained that the martial arts structure consists of 4 (four) important bases which are united and inseparable, namely: tide (stance), stride (step pattern), attack and defense [2].

\section{METHOD}

This research applied the qualitative research with a Historical Research approach. The Historical research seeks to reconstruct facts in the past about what, who, when, where and how objectively, systematically and accurately was carried out in present time. The reconstruction process was performed based on the results of the field records, artifacts and verbal reports of perpetrators or historical witness.

This research was conducted in three regencies; 1) first, Pangunraun Pitu in East Barito regency, which there were three villages as research sites: Tampa village, Unsum village and Hayaping village. 2) Second, Silat Sakti Salamat Kambe in Katingan regency, which was in Jahanjang village, Kamipang district. 3) Third, Palampang Panerus Tinjek in Pulang Pisau regency, which was in Mintin village.

\section{RESULT}

a. Traditional martial arts history of the Central Kalimantan Dayaks

The name of Kuntau or Kuntao is derived from Chinese, which literally means "fist path." The martial art originated from China and was brought by by some Chinese people who migrated to avoid the wars occurring in their country. At that time, it was reffered to it as "Melayu Muda (young Malay)." Whereas, a long time ago, there were also people from Yunan who migrated around 4000-1500 BC before being spread throughout Southeast Asia, they were called "Melayu Tua" or "Proto-Melayu." At that time, there was assimilation between Chinese immigrants and indigenous people. The immigrants - some of them, mastered martial arts and lived side by side with the local community through marriage, business partnership, and martial arts. So, there was an acculturation of culture and martial arts.

The relationship between traditional Dayak martial arts and Chinese martial arts manifested into the name "Kuntao," however, this does not necessarily imply that the traditional Dayak martial arts originated from China. Although, it does not directly relate the origin of the Dayak tribe from China, researchers drew a conclusion that there is an influence of Kuntao's martial arts which originates from China on the traditional Dayak martial arts in Central Kalimantan especially with the spread of Kuntao from China to other countries such as Malaysia, Thailand, Vietnam, Philippines and Indonesia. Although the name of Kuntao is widely used in several regions, however, it is different in Central Kalimantan where it is called as Kuntau Bangkui.

Some of the people that played major roles in spreading traditional Dayak martial arts in Central Kalimantan include; 
Mahusin Saun (1873-1990) or famously known as Tinjek, Salamat Kambe or famously known as Salamat Saun (18871983). They are both brothers and the linage satarts from Sawang; Sawang has a child named Saun, Saun has children named Mahusin Saun (Tinjek) and Salamat Saun (Kambe).

According to information from practitioners of traditional Dayak martial arts in Central Kalimantan, Mahusin Saun (Tinjek) and Salamat Saun (Kambe) had several teachers and also studied Betawi and Cimande martial arts, then there is a genre of Wild Betawi.

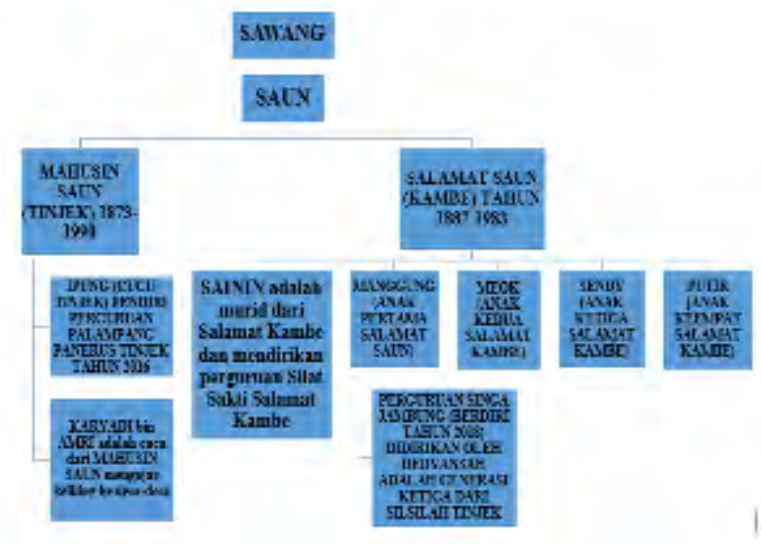

Fig. 1. Family's tree of Mahusin Saun (Tinjek) and Salamat Saun (Kambe)

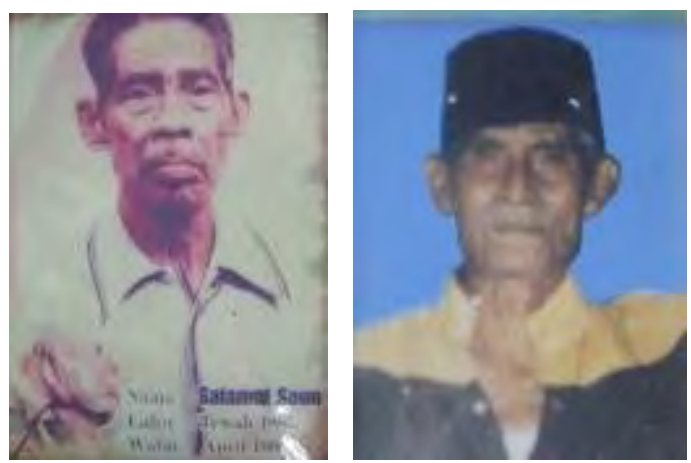

Fig. 2. Salamat Kambe (left) and Tinjek (right) (Source: extended family of Salamat Kambe and Tinjek)

Kuntau Traditional Martial Arts College Pangunraun Pitu was founded on March 13, 2011 by three people. The founders include; Antonius Limpau, Ketman, and Misranto in the village of Tewah Pupu, Barito Timur regency, Central Kalimantan.

The Silat Sakti Salamat Kambe was founded around 2015 in Jahanjang village, Kamipang District, Katingan regency, Central Kalimantan, and it was founded by Sainin and Sarwepin. The trainer in this college (Sainin) is a student of Salamat Kambe, and in 2018 he joined the Tinjek-Salamat Kambe Singer College.

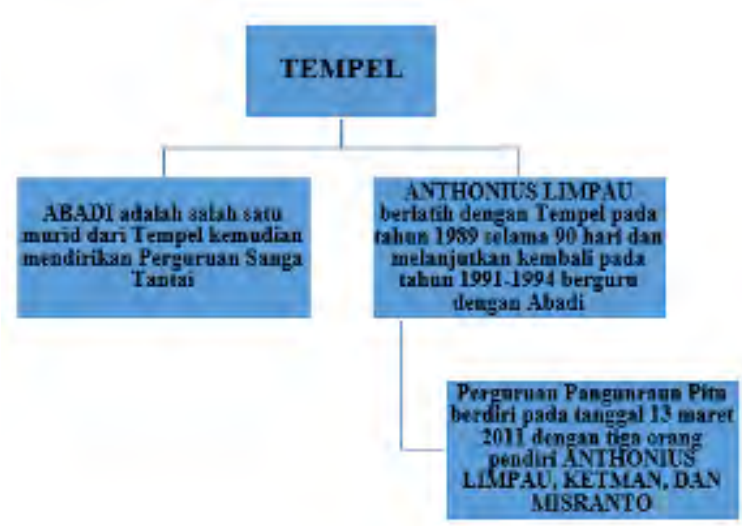

Fig. 3. Family's tree of Pangunraun Pitu

The Galanggang Palampang Panerus Tinjek was officially founded in 2016 by Ipung I. Anjur. He is the grandson of Mahusin Saun (Tinjek). The perguruan is located in Mintin village, Pulang Pisau regency, Central Kalimantan.

b. Philosophy in the traditional martial arts of the Central Kalimantan Dayak tribe

The Pangunraun Pitu otherwise known as Pangunraun, is a collection of literary languages with very a beautiful display of language, not harsh or soft. The second "Pitu," is a result of the addition of "four" plus "three." The four represents human-owned entities, for example, there are east, west, north, and south, as the direction of the universe, so four is owned by humans who live on earth. Then, the philosophy of the three is to describe the entity of "God," which in the Christian beliefs are; God the Father who created the universe, Jesus Christ the Son, and the third, the Holy Spirit, which is collectively reffered to as the Trinity. Overall, the philosophy of "Pitu" is a combination of characteristics possessed by humans and characteristics possessed by God, which is the philosophical value the name of Pangunraun Pitu.

The meaning of the name Palampang Panerus Tinjek is the appointment and successor of Tinjek. The name of Tinjek is famously known among the traditional Dayak martial arts activists or usually called Kuntau. They are on of the figures with major roles in spreading the traditional Dayak martial arts throughout Central Kalimantan. The "Sleeping tiger should not be disturbed" is the watchword of the Palampang Panerus Tinjek, and according to Ipung the trainer and founder of this college, means that a quiet human being should not be disturbed and if disturbed, the tiger will pounce viciously on you. This implies never to disturb people, even if they seem like they cannot fight. However, if they fight you, they will bear the risk themselves. 
Generally, the main philosophy in traditional Dayak martial arts contains Islamic values and teachings, especially when focusing on the genre of Mahusin Saun (Tinjek) and Salamat Saun (Salamat Kambe). They are immersed fully in Islamic values in almost every movement especially in the step pattern. For example, in the Epat step where the step moves to make a form the alif lam mim which means "Only God Knows."

c. Central Kalimantan Dayak traditional martial arts techniques

The characteristics of the Central Kalimantan Dayak tribal martial arts is the use of various low stances.

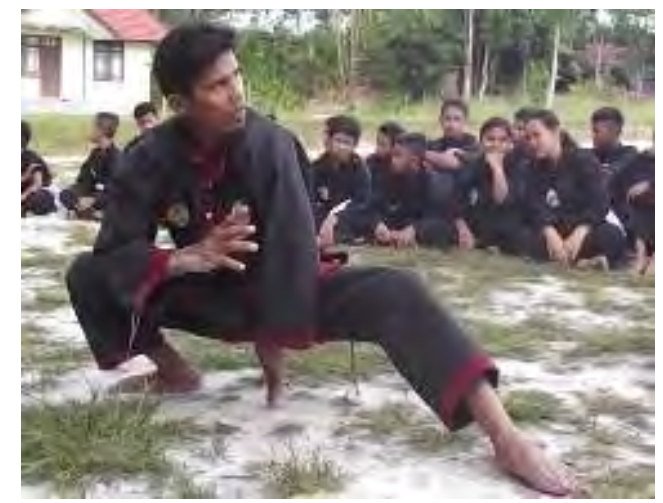

Fig. 4. Stance of Jurus Bangkui

The traditional self-defense of Dayak tribe is one of the close combat methods, and one of the characteristic is seen from the pattern of short blows and immediate withdrawals. The blows are fast and targeted at the lower body.

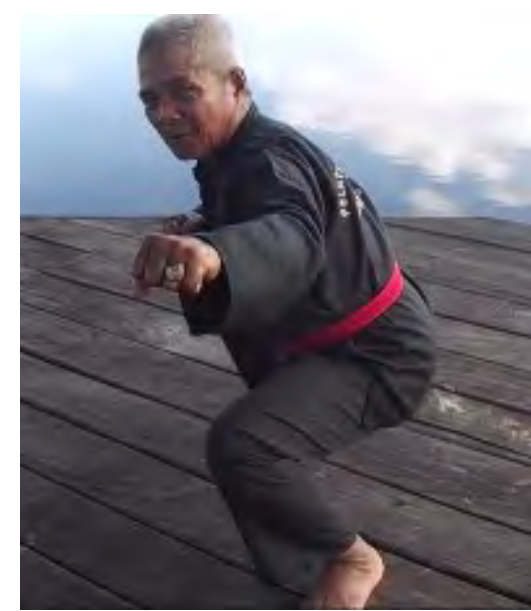

Fig. 5. Bangkui punch (susul)

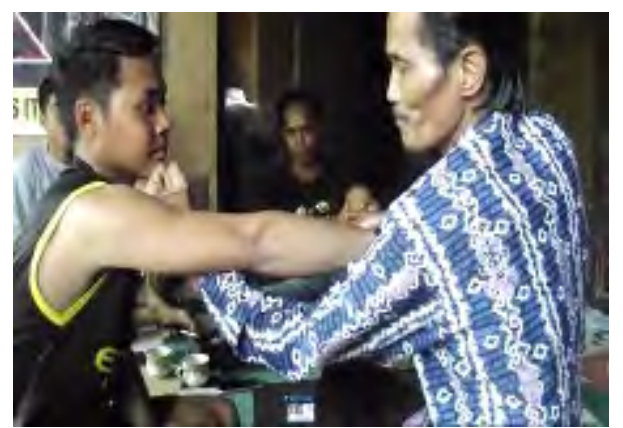

Fig. 6. Bangkui punch, Called jurus tidur sekejap pencuri datang

The traditional self-defense of the Dayak tribe in Central Kalimantan which is also referred as Kuntau uses a lot of attacks such guntingan and locks or commonly known as the Bangkui lock.

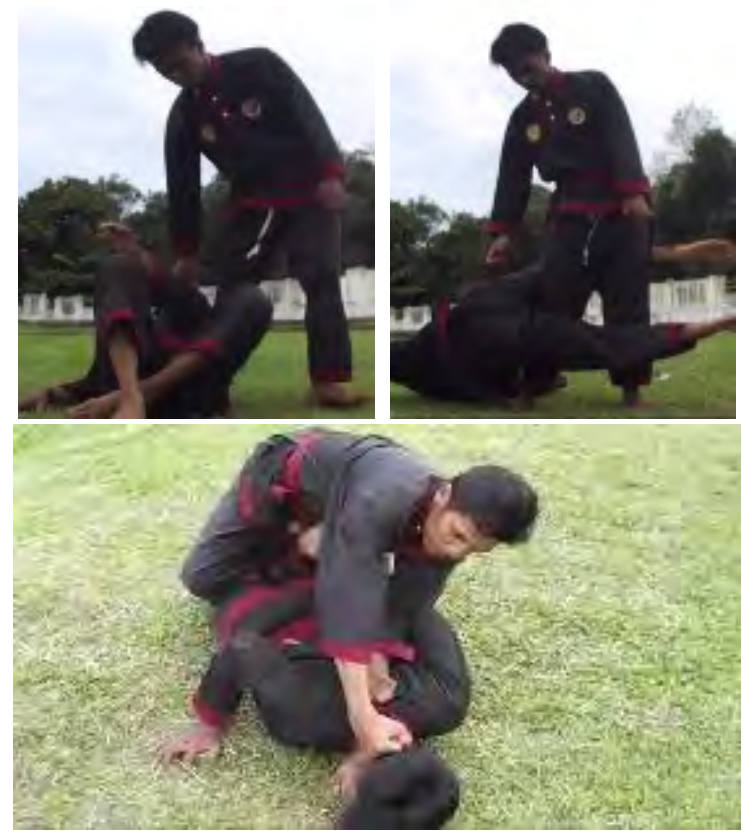

Fig. 7. Jurus Guntingan Bangkui

A feature of the traditional Central Kalimantan Dayak tribal martial arts can be seen in half kicks; this means that no kick exceeds the waist height target.

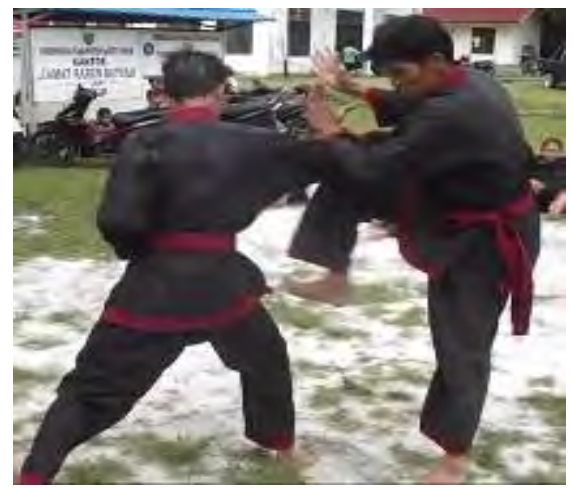

Fig. 8. Jurus Tandang Satengh (half kick) 


\section{CONCLUSIONS}

People who played major roles in spreading traditional Dayak martial arts in Central Kalimantan also known as Kuntau or Main, are the brothers Mahusin Saun; famously known as Tinjek, and Salamat Kambe; famously known as Salamat Saun..

Generally, the main philosophy in traditional Dayak martial arts contains the chritian religion in Pangunraun pitu and Islamic values in Silat Sakti Salamat and Palampang panerus Tinjek. This occurs mostly when the focu is on the genre of Mahusin Saun and Salamat Saun. Islamic values exists in almost every movement especially in the step pattern drawn from Arabic letters such as alif lam mim.

The characteristics of the Central Kalimantan Dayak traditional martial arts is the low stance and the blows are mostly directed towards the lower body and use attacks in the form of cutouts and locks or commonly referred to as Bangkui stance. This traditional Dayak tribal self-defense is one of the close combat methods.

\section{REFERENCES}

[1] N. Riwut, Maneser panatau tatu hiang: Menyelami Kekayaan Leluhur. (cetakan ke-2). Yogyakarta: NR Publishing. 2015

[2] Siswantoyo, Napak tilas jejak pencak silat. Yogyakarta. Fakultas Ilmu Keolahragaan Universitas Negeri Yogyakarta. 2008

[3] Lubis, Johansyah, Pencak silat. Jakarta: Rajawali Sport, 2014.

[4] E. S. Kriswanto, Pencak silat-sejarah dan perkembangan pencak silat, teknik-teknik dalam pencak silat, pengetahuan dasar pencak silat. Yogyakarta: Pustaka baru Press, 2015. 